\title{
Analisis Rasio Keuangan Pengukur Kinerja Perusahaan dan Pengaruhnya Terhadap Harga Saham dan Ekspektasi Return Saham sebagai Bahan Pengambilan Keputusan bagi Investor
}

\author{
Yarnest ${ }^{1}$ \\ 1Pendidikan Ekonomi-Universitas Negeri Malang
}

\section{INFO ARTIKEL}

Riwayat Artikel:

Diterima: 20 juni 2019

Disetujui: 17 Oktober 2019

\section{Kata kunci:}

Rasio keuangan

Harga saham

Ekspektasi return saham

Pengambilan keputusan

\author{
Alamat Korespondensi: \\ Yarnest \\ Pendidikan Ekonomi \\ Pascasarjana Universitas Negeri Malang \\ Jalan Semarang 5, Malang 65154 \\ E-mail: yar.nest@yahoo.co.id
}

\begin{abstract}
This research intent for description and analysis: how big finance ratios can measure firm performance on corporate BUMN that listing at Indonesian stock exchange; ratio factor influence liquidity, leverage's ratio, activity ratio, profitability ratio. This research utilizes design ex post facto, meanwhile analysis's tech that is utilized which is analysis multiple regression, test $F$ and test $t$. Substantial's ala usufructs to test correlasionality points out that variable second that assigns value that negative. This observational finding betokens, that stock price variable increases or down, therefore expected return stock will experience decrease or step-up. Stock ratio that measured by price to book value share constituting dominant factor that regard stock price, meanwhile liquidity ratio that measured by quick (acid is test) constituting factor dominating to regard expected return stock.
\end{abstract}

\begin{abstract}
Abstrak: Penelitian ini bertujuan untuk mendiskripsikan dan menganalisis : bagaimana kinerja perusahaan BUMN yang listing di Bursa Efek Indonesia di ukur dari rasio-rasio keuangan. Penelitian ini menggunakan rancangan ex post facto, sedangkan teknik analisis yang digunakan yaitu analisis multiple regression dengan program Eviews, uji $\mathrm{F}$ dan uji t. Secara substansial hasil uji korelasionalitas menunjukkan bahwa kedua variabel tersebut memberikan nilai yang negatif. Temuan penelitian ini mengindikasikan, bahwa variabel harga saham meningkat atau menurun, maka ekspektasi return saham akan mengalami penurunan atau peningkatan. Faktor rasio keuangan sebagai pengukur kenerja perusahaan, harga saham dan ekspektasi return saham menjadi bahan pertimbangan dalam pengambilan keputusan investor dalam berinvestasi pada perusahaan BUMN yang listing di Bursa Efek Indonesia.
\end{abstract}

Kinerja perusahaan, merupakan alat perencanaan dan pengendalian bagi pimpinan dan investor dalam periode waktu tertentu. Dengan mengukur kinerja perusahaan, maka dapat diperoleh informasi (data) untuk membantu proses pengambilan keputusan dan dapat memberi dasar yang baik bagi manajemen perusahaan secara keseluruhan. Pengukuran kinerja perusahaan menurut (Supriyono, 1999) adalah proses untuk menentukan seberapa baik aktivitas-aktivitas bisnis dilaksanakan untuk mencapai tujuan strategis, mengeliminasi pemborosan-pemborosan dan menyajikan informasi tepat waktu untuk melaksanakan penyempurnaan secara berkesinambungan. Menurut Anthony, Baker, Kaplan dan Young dalam (Yuwono, Sukarno, \& Ichsan, 2002) mendefinisikan kinerja perusahaan adalah merupakan pengukuran yang dilakukan 
terhadap berbagai aktivitas dalam rantai nilai yang ada dalam perusahaan. Pengukuran kinerja perusahaan dapat dilakukan berdasarkan analisis rasio keuangan.

Pengelolaan perusahaan yang efektif dan kebijakan manajemen yang mengacu kepada peningkatan share holder value, akan menjadi tolok ukur bagi para investor dan funds managers. Para investor dan funds managers akan melakukan seleksi secara ketat dalam menentukan pilihan investasinya. Beberapa hal yang sangat penting dalam pengambilan keputusan investasi yang dilakukan Investor, adalah : berapa tingkat pengembalian yang diharapkan, berapa besar risiko yang harus ditanggungnya dan bagaimana likuiditas investasi tersebut, serta bagaimana pengaruh kondisi faktor Internal perusahaan. Investor akan mengumpulkan sebanyak mungkin informasi yang berguna dalam pengambilan keputusan investasi, antara lain harga saham, kinerja perusahaan (laporan keuangan maupun laporan lainnya) (Harianto \& Sudomo, 1998).

Hanya perusahaan yang memiliki kinerja yang baik saja, yang akan mendapatkan tempat dalam keputusan yang diambil para investor dan funds managers. Kinerja perusahaan biasanya dijadikan indikator yang sering dipakai untuk memilih investasi bagi investor. Investor yang menginvestasikan dananya pada sekuritas, sangat berkepentingan terhadap keuntungan saat ini dan keuntungan yang diharapkan di masa yang akan datang serta adanya stabilitas dari keuntungan yang akan diperoleh. Sebelum menginvestasikan dananya investor melakukan analisis terhadap kemampuan perusahaan menghasilkan keuntungan. Investor juga berkepentingan atas informasi yang berhubungan dengan kondisi atau kinerja perusahaan sebagai pedoman untuk melakukan investasi, agar dana yang diinvestasikan tersebut mampu menghasilkan nilai tambah di masa mendatang dalam bentuk dividen dan atau capital gain.

Alat analisa yang sering dipakai adalah analisa rasio, dimana analisa ini memberikan gambaran ukuran dari hubungan dua macam data. Analisa rasio mengukur hubungan antara data-data keuangan yang ada pada Neraca dan Laporan Rugi dan Laba. Analisa rasio ini dikelompokkan dalam 5 kategori, yaitu : 1) Rasio likuiditas yaitu rasio yang digunakan untuk mengetahui kemampuan membayar dari suatu perusahaan. 2) Rasio leverage yaitu rasio yang digunakan untuk mengukur perbandingan antara aktiva yang dimiliki perusahaan dengan hutang-hutangnya. 3) Rasio aktivitas yaitu rasio yang digunakan untuk mengukur kegiatan aktivitas perusahaan. 4) Rasio profitabilitas yaitu rasio yang digunakan untuk mengukur tingkat keuntungan dari kegiatan operasi perusahaan. 5) Rasio saham yaitu rasio yang menunjukkan bagian dari laba perusahaan, dividen, dan modal yang dibagikan kepada setiap saham.

Harga saham di bursa bersifat dinamis yang menyebabkan sulit ditentukan. Harga saham dapat bergerak naik dan turun karena faktor psikologis, akan tetapi dasar dan sekaligus titik awal penilaian suatu saham tertentu tetap pada kinerja perusahaan. Apabila terjadi kenaikan permintaan saham suatu perusahaan akan mengakibatkan kenaikan pada harga saham tersebut. Oleh karena itu investor akan mencoba menganalisis faktor yang bersifat fundamental yang diperkirakan akan memepengaruhi harga saham.

Dalam kaitannya dengan investasi pada saham, investor ingin mendapatkan return yang besar atau tinggi dari dana yang diinvestasikannya pada sekuritas, ini dapat dilihat dari harga saham yang tinggi. Ekspektasi return saham dapat dipengaruhi oleh kinerja keuangan perusahaan yang dapat diukur dari rasio keuangan.

Penelitian ini bertujuan untuk mendiskripsikan dan menganalisis: 1) Bagaimana kinerja perusahaan BUMN yang listing di Bursa Efek Indonesia diukur dari rasio-rasio keuangan. 2) Pengaruh faktor Rasio Likuiditas (Liquidity Ratio), Rasio Leverage (Leverage Ratio), Rasio Aktivitas (Activity Ratio), Rasio Profitabilitas (Profitability Ratio) dan Rasio Saham (Common Stock Ratio) secara parsial dan simultan terhadap Harga Saham perusahaan BUMN yang listing di Bursa Efek Indonesia. 3) Pengaruh faktor Rasio Likuiditas (Liquidity Ratio), Rasio Leverage (Leverage Ratio), Rasio Aktivitas (Activity Ratio), Rasio Profitabilitas (Profitability Ratio) dan Rasio Saham (Common Stock Ratio) secara parsial dan simultan terhadap Ekspektasi Return Saham perusahaan BUMN yang listing di Bursa Efek Indonesia. 4) Manakah dari faktor Rasio Likuiditas (Liquidity Ratio), Rasio Leverage (Leverage Ratio), Rasio Aktivitas (Activity Ratio), Rasio Profitabilitas (Profitability Ratio) dan Rasio Saham (Common Stock Ratio) yang berpengaruh dominan terhadap Harga Saham dan Ekspektasi Return Saham perusahaan BUMN yang listing di Bursa Efek Indonesia. 5) Pengaruh faktor Harga saham perusahaan terhadap Ekspektasi Return Saham perusahaan BUMN yang listing di Bursa Efek Indonesia. 6) Apakah faktor rasio keuangan pengukur kinerja perusahaan, harga saham dan ekspektasi return saham menjadi bahan pertimbangan bagi investor dalam pengambilan keputusan berinvestasi pada perusahaan BUMN yang listing di Bursa efek Indonesia. 


\section{Kerangka Konseptual Penelitian}

Rasio keuangan yang terdiri dari rasio likuiditas, leverage, aktivitas, profitabilitas dan rasio saham akan mencerminkan kinerja perusahaan. Faktor kinerja perusahaan harga saham dan ekspektasi return saham dapat berpengaruh terhadap pengambilan keputusan investor dalam berinvestasi pada perusahaan BUMN yang listing di Bursa Efek Indonesia seperti yang terlihat gambar kerangka hubungan variabel di bawah ini.

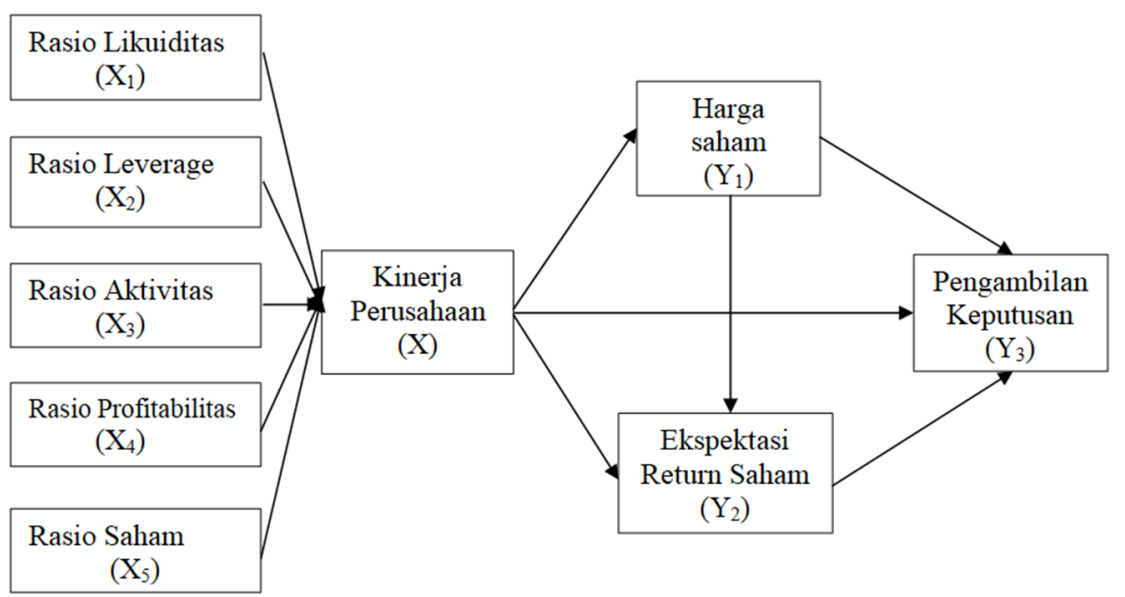

Gambar 1. Kerangka Hubungan Konseptual Variabel

\section{METODE}

Penelitian ini menggunakan rancangan ex post facto, penelitian dilakukan pada perusahaan BUMN yang listing di Bursa Efek Indonesia dengan tujuan untuk mengetahui hubungan atau pengaruh antara variabel bebas dengan variabel terikat dan kemudian surut ke belakang untuk mengetahui faktor rasio keuangan pengukur kinerja perusahaan yang dapat menimbulkan pengaruh terhadap harga saham perusahaan dan hubungannya dengan ekspektasi return saham serta apakah kinerja perusahaan, harga saham dan ekspektasi return saham menjadi bahan pertimbangan bagi investor dalam pengambilan keputusan berinvestasi.

Populasi penelitian adalah seluruh perusahaan BUMN yang listing di Bursa Efek Indonesia (BEI). Pertimbangan peneliti mengambil obyek perusahaan BUMN adalah karena: (1) peranan negara dalam bidang ekonomi sangat penting ketika banyak ahli ekonomi percaya bahwa mekanisme pasar tidak dapat menyelesaikan semua persoalan ekonomi (Rachbini, 1992). Campur tangan negara (pemerintah) diperlukan untuk mengurangi dampak kegagalan pasar, kekakuan harga dan dampak eksternalitas pada lingkungan alam dan social. (2) melalui pasar modal (listing) dapat menciptakan iklim pengelolaan perusahaan (BUMN) yang sehat, karena menyebarkan pemilikan, keterbukaan dan profesionalisme. (3) membangun iklim keterbukaan bagi dunia usaha (BUMN), karena adanya transparansi dalam pengelolaan, pembukuan dan laporan keuangan. (4) terbuka peluang terjadinya kontrol sosial oleh masyarakat, investor dan pemerintah.

Data yang digunakan dalam penelitian ini adalah data sekunder dan data primer. Data sekunder berasal dari: a) Data tentang laporan keuangan perusahaan BUMN yang listing di BEI dari tahun 2004-2008. b) Data tentang annual report perusahaan BUMN yang listing di BEI dari tahun 2004-2008. c) Capital market directory pada Bursa Efek Indonesia (BEI), JSX statistik, homepage BEI maupun laporan berkala BEI. d) Data yang diinginkan dalam penelitian ini adalah data tahunan yang mengacu dari penelitian. (Kothari, Shanken, \& Sloan, 1995). Data primer, diperoleh dari para investor melalui pasar sekuritas yang ada di Malang dan Surabaya, dengan menggunakan kuesioner sebagai alat pengumpulan data. Jumlah sampel dari data primer diambil sebanyak 150 orang responden dengan menggunakan teknik simple random sampling.

Teknik yang digunakan untuk pengumpulan data adalah, teknik dokumenter untuk data sekunder yang diperoleh dari perusahaan BUMN yang listing di Bursa Efek Indonesia, yaitu berupa laporan keuangan dan haga saham masing-masing perusahaan dari tahun 2004 - 2008 dan menggunakan alat kuesioner untuk mengumpulkan data primer, berupa penyataan dari responden atau investor berkaitan dengan apa yang 
menjadi bahan dalam pengambilan keputusan untuk berinvestasi pada perusahaan BUMN yang listing di Bursa Efek Indonesia kemudian data dianalisis dengan pendekatan kuantitatif. Teknik analisis yang digunakan yaitu analisis regresi berganda, uji $\mathrm{F}$ dan uji t dengan menggunakan software Aviews versi 6.0 untuk menganalisis panel data.

\section{HASIL}

\section{Analisis Kinerja}

Aspek likuditas (Tabel 1) berkaitan dengan kemampuan perusahaan dalam membayar kewajiban jangka pendek. Indikator yang digunakan dalam aspek likuiditas diantaranya adalah current ratio, cash ratio, quick (acid test) dan working capital to total asset ratio.

Tabel 1. Analisis Rasio Likuiditas Perusahaan Perusahaan BUMN yang Listing di Bursa Efek Indonesia

\begin{tabular}{cccccc}
\hline No & Nama Perusahaan & $\begin{array}{c}\text { Current } \\
\text { Ratio }\end{array}$ & $\begin{array}{c}\text { Cash } \\
\text { Ratio }\end{array}$ & $\begin{array}{c}\text { Quick (Acid } \\
\text { Test) }\end{array}$ & $\begin{array}{c}\text { Working Capital } \\
\text { to } \\
\text { Total Asset Ratio }\end{array}$ \\
\hline 1 & & & 1,05 & 0,57 & 4,69 \\
2 & PT. Bank Negara Indonesia Tbk & 1,05 & 1,24 & 0,82 & 18,94 \\
3 & PT. Bank Rakyat Indonesia Tbk & 1,24 & 1,08 & 0,88 & 7,54 \\
4 & PT. Bank Mandiri Tbk & 1,08 & 1,18 & 0,55 & 24,49 \\
5 & PT. Adhi Karya Tbk & 1,29 & 1,16 & 4,44 & 24,38 \\
6 & PT. Wijaya Karya Tbk & 1,40 & 1,26 & 0,77 & 32,00 \\
7 & PT. Indofarma Tbk & 3,45 & 2,12 & 1,09 & 36,70 \\
8 & PT. Kimia Farma Tbk & 2,11 & 3,26 & 4,93 & 36,86 \\
9 & PT. Aneka Tambang Tbk & 4,24 & 1,09 & 2,83 & 15,77 \\
10 & PT. Timah Persero Tbk & 2,30 & 2,21 & 2,14 & 57,41 \\
11 & PT. Gas Negara Tbk & 2,43 & 3,87 & 9,56 & $-7,57$ \\
12 & PT. Tam. Batu Bara Bukit Asam & 4,31 & 0,70 & 1,48 & 33,14 \\
13 & Tbk & 0,71 & 2,03 & 3,20 \\
\hline
\end{tabular}

Sumber : Data diolah, 2010.

Berdasarkan analisis dengan menggunakan rasio likuiditas (Tabel 1) menunjukkan bahwa dari ketigabelas perusahaan BUMN memiliki tingkat likuiditas. Tingkat likuiditas yang tertinggi adalah PT. Tambang Batu Bara Bukit Asam Tbk. Tingginya tingkat likuiditas mengindikasikan bahwa PT. Tambang Batu Bara Bukit Asam Tbk memiliki kemampuan yang lebih baik dalam memenuhi kewajiban jangka pendeknya. Sedangkan pada PT. Telkom Tbk memiliki tingkat likuiditas kurang baik. Hal ini berarti PT. PT. Telkom Tbk, Tbk cukup mampu dalam memenuhi kewajiban jangka pendeknya.

Aspek leverage (Tabel 2) berhubungan dengan kemampuan perusahaan dalam memenuhi semua kewajiban baik jangka panjang maupun jangka pendek. Indikator yang digunakan dalam aspek leverage diantaranya adalah total debt to equity ratio, total debt to total capital assets, long term debt to equity ratio, tangible assets debt coverage, dan time interest earned ratio. Berdasarkan analisis dengan menggunakan rasio leverage (Tabel 2) menunjukkan bahwa dari ketigabelas perusahaan kosmetik memiliki tingkat solvabilitas yang berbeda. Tingkat solvabilitas yang paling baik adalah PT. Bank Negara Indonesia, Tbk. Hal ini dikarenakan PT. Bank Negara Indonesia, Tbk memiliki rasio utang yang lebih rendah sehingga perusahaan mempunyai kemampuan yang lebih baik dalam memenuhi semua utangnya baik jangka panjang maupun jangka pendek. Sedangkan pada PT Semen Gresik, Tbk tingkat solvabilitasnya cukup tinggi sehingga perusahaan kurang mampu memenuhi semua utangnya baik jangka panjang maupun jangka pendek. 
Tabel 2. Analisis Rasio Leverage Perusahaan Perusahaan BUMN yang Listing di Bursa Efek Indonesia

\begin{tabular}{|c|c|c|c|c|c|c|}
\hline No & Nama Perusahaan & $\begin{array}{l}\text { Total Debt to } \\
\text { Equity Ratio }\end{array}$ & $\begin{array}{l}\text { Total debt to } \\
\text { total capital } \\
\text { assets }\end{array}$ & $\begin{array}{c}\text { Long } \\
\text { term debt to } \\
\text { equity ratio }\end{array}$ & $\begin{array}{l}\text { Tangible assets } \\
\text { debt coverage }\end{array}$ & $\begin{array}{l}\text { Time Interest } \\
\text { Earned Ratio }\end{array}$ \\
\hline 1 & $\begin{array}{l}\text { PT. Bank Negara } \\
\text { Indonesia Tbk }\end{array}$ & 1091,40 & 94,68 & 0,10 & 271,67 & 0,00 \\
\hline 2 & $\begin{array}{l}\text { PT. Bank Rakyat } \\
\text { Indonesia Tbk }\end{array}$ & 1385,20 & 105,77 & 0,11 & 79,56 & 0,00 \\
\hline 3 & $\begin{array}{l}\text { PT. Bank Mandiri } \\
\text { Tbk }\end{array}$ & 1308,60 & 92,98 & 0,09 & 460,72 & 0,00 \\
\hline 4 & PT. Adhi Karya Tbk & 250,60 & 138,26 & 6,08 & 31,41 & 0,85 \\
\hline 5 & $\begin{array}{c}\text { PT. Wijaya Karya } \\
\text { Tbk }\end{array}$ & 134,00 & 89,53 & 3,04 & 251,22 & 0,54 \\
\hline 6 & PT. Indofarma Tbk & 89,80 & 65,98 & 1,64 & 114,94 & 0,60 \\
\hline 7 & PT. Kimia Farma Tbk & 158,00 & 109,08 & 0,47 & 236,54 & 0,32 \\
\hline 8 & $\begin{array}{c}\text { PT . A neka T ambang } \\
\text { T bk }\end{array}$ & 1374,80 & 501,70 & 0,78 & 424,02 & 0,40 \\
\hline 9 & $\begin{array}{c}\text { PT . T imah Persero } \\
\text { T bk }\end{array}$ & 2160,80 & 282,58 & 0,67 & 416,73 & 0,40 \\
\hline 10 & PT. G as N egara T bk & 901,40 & 213,90 & 2,10 & 173,48 & 0,64 \\
\hline 11 & $\begin{array}{c}\text { PT. T amb. Batu Bara } \\
\text { Bukit Asam T bk }\end{array}$ & 996,00 & 559,80 & 0,43 & 709,68 & 0,29 \\
\hline 12 & PT. T elkom T bk & 1364,40 & 148,10 & 1,43 & 464,12 & 0,53 \\
\hline 13 & $\begin{array}{l}\text { PT . Semen G resik } \\
\text { T bk }\end{array}$ & 5084,20 & 696,99 & 0,47 & 421,96 & 0,30 \\
\hline & Rata-rata Industri & 2,55 & 238,41 & 1,34 & 312,00 & 0,38 \\
\hline
\end{tabular}

Sumber : Data diolah, 2010.

Tabel 3. Analisis Rasio Aktivitas Perusahaan Perusahaan BUMN yang Listing di Bursa Efek Indonesia

\begin{tabular}{|c|c|c|c|c|c|c|c|}
\hline No & Nama Perusahaan & $\begin{array}{c}\text { Total } \\
\text { Assets } \\
\text { Turnove } \\
r\end{array}$ & $\begin{array}{l}\text { Receivable } \\
\text { s turnover }\end{array}$ & $\begin{array}{c}\text { Average } \\
\text { collection } \\
\text { periode }\end{array}$ & $\begin{array}{c}\text { Inventory } \\
\text { turnover }\end{array}$ & $\begin{array}{c}\text { Average } \\
\text { day's } \\
\text { inventory }\end{array}$ & $\begin{array}{c}\text { Working } \\
\text { capital } \\
\text { turnover }\end{array}$ \\
\hline 1 & $\begin{array}{l}\text { PT. Bank Negara } \\
\text { Indonesia Tbk }\end{array}$ & 4,61 & 0,14 & 37,95 & 0,00 & 0,00 & 1,13 \\
\hline 2 & $\begin{array}{l}\text { PT. Bank Rakyat } \\
\text { Indonesia Tbk }\end{array}$ & 1,39 & 0,39 & 48,83 & 0,00 & 0,00 & 0,68 \\
\hline 3 & PT. Bank Mandiri Tbk & 3,67 & 0,21 & 59,83 & 0,00 & 0,00 & 0,51 \\
\hline 4 & PT. Adhi Karya Tbk & 1,35 & 30,21 & 18,49 & 17,49 & 226,35 & 7,66 \\
\hline 5 & PT. Wijaya Karya Tbk & 3,00 & 0,07 & 55,55 & 4,90 & 49,41 & 5,28 \\
\hline 6 & PT. Indofarma Tbk & 1,38 & 19,08 & 95,53 & 1,38 & 74,43 & 5,74 \\
\hline 7 & PT. Kimia Farma Tbk & 1,70 & 40,74 & 66,58 & 2,03 & 64,16 & 5,32 \\
\hline 8 & PT. Aneka Tambang Tbk & 0,74 & 22,70 & 87,72 & 3,77 & 98,12 & 2,08 \\
\hline 9 & PT. Timah Persero Tbk & 1,37 & 18,98 & 36,18 & 2,48 & 131,37 & 3,86 \\
\hline 10 & PT. Gas Negara Tbk & 0,44 & 25,96 & 104,69 & 0,00 & 84,15 & 6,72 \\
\hline 11 & $\begin{array}{l}\text { PT. Tamb. Batu Bara } \\
\text { Bukit Asam Tbk }\end{array}$ & 1,10 & 13,95 & 84,84 & 8,80 & 41,31 & 1,93 \\
\hline 12 & PT. Telkom Tbk & 0,67 & 16,87 & 62,27 & 115,45 & 24,24 & $-10,34$ \\
\hline \multirow[t]{2}{*}{13} & PT. Semen Gresik Tbk & 1,08 & 30,06 & 49,42 & 4,74 & 76,67 & 3,73 \\
\hline & Rata-rata Industri & 1,73 & 16,87 & 62,14 & 12,39 & 66,94 & 2,64 \\
\hline
\end{tabular}

Sumber : Data diolah, 2010. 
Aspek aktivitas berhubungan dengan efektivitas perusahaan dalam mengoperasikan dana. Indikator yang digunakan dalam aspek aktivitas diantaranya adalah total assets turnover, receivables turnover, average collection periode, inventory turnover, average day's inventory, dan working capital turnover. Berdasarkan analisis dengan menggunakan rasio aktivitas (Tabel 3) menunjukkan bahwa dari ketiga belas perusahaan BUMN memiliki tingkat aktivitas yang berbeda. Tingkat aktivitas yang paling baik adalah PT Bank Negara Indonesia Tbk, hal ini menunjukkan bahwa PT Bank Negara Indonesia Tbk paling efektif dalam mengoperasikan dana. Sedangkan PT Adhi Karya Tbk tingkat aktivitasnya kurang baik. Hal ini menggambarkan bahwa PT Adhi Karya Tbk kurang efektif dalam mengoperasikan dana perusahaan.

Tabel 4. Analisis Rasio Profitabilitas Perusahaan Perusahaan BUMN yang Listing di Bursa Efek Indonesia

\begin{tabular}{|c|c|c|c|c|c|c|c|}
\hline No & Nama Perusahaan & $\begin{array}{l}\text { Gross profit } \\
\text { margin }\end{array}$ & $\begin{array}{c}\text { Operating } \\
\text { ncome } \\
\text { ratio }\end{array}$ & $\begin{array}{l}\text { Net profit } \\
\text { margin }\end{array}$ & $\boldsymbol{R O A}$ & ROI & $\begin{array}{l}\text { Rate of } \\
\text { Return } \\
\text { for the } \\
\text { Owner }\end{array}$ \\
\hline 1 & $\begin{array}{c}\text { PT. Bank Negara Indonesia } \\
\text { Tbk }\end{array}$ & 0,08 & 0,21 & 0,14 & 1,45 & 1,05 & 12,41 \\
\hline 2 & $\begin{array}{c}\text { PT. Bank Rakyat Indonesia } \\
\text { Tbk }\end{array}$ & 0,61 & 0,29 & 0,20 & 4,23 & 2,81 & 26,89 \\
\hline 3 & PT. Bank Mandiri Tbk & 0,34 & 0,19 & 0,13 & 1,77 & 1,22 & 13,03 \\
\hline 4 & PT. Adhi Karya Tbk & 0,09 & 0,06 & 0,02 & 4,29 & 2,98 & 20,18 \\
\hline 5 & PT. Wijaya Karya Tbk & 0,04 & 0,03 & 0,07 & 4,71 & 3,71 & 21,83 \\
\hline 6 & PT. Indofarma Tbk & 0,00 & 5,26 & 0,97 & 3,40 & 1,41 & 3,48 \\
\hline 7 & PT. Kimia Farma Tbk & 0,00 & 0,04 & 0,03 & 7,10 & 4,52 & 6,61 \\
\hline 8 & PT. Aneka Tambang Tbk & 0,46 & 0,37 & 0,28 & 29,54 & 20,73 & 34,41 \\
\hline 9 & PT. Timah Persero Tbk & 0,24 & 0,16 & 0,10 & 23,88 & 15,19 & 23,89 \\
\hline 10 & PT. Gas Negara Tbk & 0,00 & 0,32 & 0,15 & 6,59 & 4,12 & 46,48 \\
\hline 11 & $\begin{array}{c}\text { PT. Tamb. Batu Bara Bukit } \\
\text { Asam Tbk }\end{array}$ & 0,41 & 0,23 & 0,18 & 27,17 & 19,18 & 27,72 \\
\hline 12 & PT. Telkom Tbk & 0,00 & 0,42 & 0,20 & 26,06 & 13,14 & 34,57 \\
\hline 13 & PT. Semen Gresik Tbk & 0,39 & 0,21 & 0,15 & 24,10 & 16,71 & 23,68 \\
\hline & Rata-rata Industri & 0,20 & 0,60 & 0,20 & 12,64 & 8,21 & 22,71 \\
\hline
\end{tabular}

Sumber : Data diolah, 2010.

Aspek profitabilitas berkaitan dengan kemampuan perusahaan dalam memperoleh keuntungan. Indikator yang digunakan dalam aspek profitabilitas diantaranya adalah gross profit margin, operating income ratio, net profit margin, ROA, ROI, dan rate of return for the owner. Berdasarkan analisis dengan menggunakan rasio profitabilitas menunjukkan bahwa dari ketiga belas perusahaan BUMN memiliki tingkat profitabilitas yang berbeda (Tabel 4). Tingkat profitabilitas yang paling baik adalah PT. Aneka Tambang Tbk. Tingginya tingkat profitabilitas menggambarkan bahwa PT. Aneka Tambang Tbk memiliki kemampuan yang lebih baik dalam memperoleh keuntungan. Sedangkan PT. Adhi Karya Tbk tingkat profitabilitasnya kurang baik. Hal ini menunjukkan bahwa PT. Adhi Karya Tbk kurang optimal dalam mendapatkan laba.

Berdasarkan Tabel 5, dapat diketahui bahwa perusahaan yang memiliki rasio saham terbaik yang PT. Timah Persero Tbk, yang berarti bahwa perusahaan mampu mampu memberikan tingkat pendapatan yang lebih besar bagi para investor, perusahaan mampu untuk membayar dividennya, sehingga mendapat kepercayaan dari investor atau pemegang saham terhadap keberhasilan perusahaan BUMN di dalam mengelola dana yang diinvestasikan pada perusahaan, sedangkan PT Indofarma Tbk memiliki rasio saham kurang baik.

\section{Hasil Uji Hipotesis Pertama}

Tidak terbukti bahwa faktor rasio likuiditas, rasio leverage, rasio aktivitas, rasio profitabilitas dan rasio saham secara parsial signifikan mempengaruhi harga saham Hasil penelitian ini mendukung penelitian (Harijono, 2006), bahwa variabel leverage ratio, current ratio, return on equity dan pertumbuhan ekonomi pengaruhnya tidak bermakna terhadap tingkat pendapatan saham perusahaan manufaktur di Indonesia, dan tidak mendukung penelitian (Zuhroh, 2004), yaitu return on investment, curret ratio, debt to quity ratio dan 
earnings per share memiliki pengaruh signifikan terhadap harga saham pada kelompok indistri farmasi di BEJ.

Tabel 5. Analisis Rasio Saham Perusahaan BUMN yang Listing di Bursa Efek Indonesia

\begin{tabular}{|c|c|c|c|c|c|c|c|c|}
\hline No & Nama Perusahaan & $\begin{array}{c}\text { Price } \\
\text { Earning } \\
\text { Ratio }\end{array}$ & EPS & DPS & $\begin{array}{l}\text { Dividen } \\
\text { Yield }\end{array}$ & $\begin{array}{l}\text { Payout } \\
\text { Ratio }\end{array}$ & $\begin{array}{l}\text { Book Value } \\
\text { per Share }\end{array}$ & $\begin{array}{c}\text { Price to } \\
\text { Book Value } \\
\text { Share }\end{array}$ \\
\hline 1 & $\begin{array}{l}\text { PT. Bank Negara } \\
\text { Indonesia Tbk }\end{array}$ & 125,20 & 222,20 & 96,20 & 0,03 & 14,08 & 29,80 & 1,90 \\
\hline 2 & $\begin{array}{l}\text { PT. Bank Rakyat } \\
\text { Indonesia Tbk }\end{array}$ & 376,91 & 369,20 & 134,00 & 0,03 & 12,16 & 36,79 & 3,29 \\
\hline 3 & $\begin{array}{c}\text { PT. Bank Mandiri } \\
\text { Tbk }\end{array}$ & 175,08 & 175,00 & 86,00 & 3,34 & 20,54 & 50,44 & 1,82 \\
\hline 4 & PT. Adhi Karya Tbk & 139,54 & 48,40 & 6,40 & 2,91 & 1,80 & 15,53 & 3,22 \\
\hline 5 & $\begin{array}{c}\text { PT. Wijaya Karya } \\
\text { Tbk }\end{array}$ & 15,04 & 21,80 & 5,80 & 1,55 & 2,42 & 25,84 & 1,59 \\
\hline 6 & PT. Indofarma Tbk & 3,11 & 3,20 & 0,00 & 0,00 & 3,10 & 0,00 & 1,43 \\
\hline 7 & PT. Kimia Farma Tbk & 10,33 & 10,20 & 2,20 & 0,02 & 5,55 & 0,22 & 1,14 \\
\hline 8 & $\begin{array}{c}\text { PT. Aneka Tambang } \\
\text { Tbk }\end{array}$ & 471,70 & 472,00 & 120,80 & 3,14 & 4,96 & 20,83 & 2,67 \\
\hline 9 & $\begin{array}{l}\text { PT. Timah Persero } \\
\text { Tbk }\end{array}$ & 320,60 & 320,60 & 808,60 & 12,98 & 2,61 & 215,68 & 9,41 \\
\hline 10 & PT. Gas Negara Tbk & 160,00 & 200,40 & 70,60 & 0,99 & 4,18 & 51,36 & 7,95 \\
\hline 11 & $\begin{array}{l}\text { PT. Tamb. Batu Bara } \\
\text { Bukit Asam Tbk }\end{array}$ & 334,80 & 333,40 & 58,60 & 2,86 & 2,27 & 28,81 & 4,36 \\
\hline 12 & PT. Telkom Tbk & 480,50 & 487,20 & 122,60 & 1,44 & 20,16 & 21,39 & 5,57 \\
\hline 13 & $\begin{array}{l}\text { PT. Semen Gresik } \\
\text { Tbk }\end{array}$ & 344,80 & $\begin{array}{c}1091,0 \\
0\end{array}$ & 126,60 & 6,72 & 5,93 & 26,38 & 3,47 \\
\hline & Rata-rata Industri & 227,51 & 288,82 & 126,03 & 2,77 & 7,67 & 40,24 & 3,68 \\
\hline
\end{tabular}

Sedangkan disisi lain terbukti bahwa faktor rasio leverage, rasio aktivitas dan rasio saham secara parsial signifikan mempengaruhi harga saham. Hal ini menunjukkan bahwa untuk menarik minat pemodal, perusahaan harus dapat menunjukkan kinerja manajemen perusahaan yang baik, juga tingkat keuntungan yang tinggi dan besarnya dividen yang akan dibagikan. Ini dapat dilihat dari laporan keuangan yang disajikan oleh perusahaan yang mencerminkan hasil operasi perusahaan secara keseluruhan. Reputasi yang baik juga sangat diperlukan oleh suatu perusahaan dalam menarik minat pemodal karena tanpa reputasi yang baik pemodal akan takut atau enggan menanamkan modalnya di perusahaan tersebut.

Informasi yang dibutuhkan oleh pemodal adalah informasi yang lengkap, akurat, relevan dan mutakhir. Tanpa semua itu pemodal tidak akan dapat menilai kinerja, operasional perusahaan dalam pengambilan keputusan investasi. Selain itu karena pemodal juga sebagai salah satu pemilik perusahaan, maka pemodal sangat berkepentingan terhadap maju mundurnya perusahaan. Pada dasarnya informasi-informasi yang diterima pemodal tentang perusahaan emiten sangat mempengaruhi besar kecilnya jumlah permintaan terhadap suatu saham di pasar modal. Hal ini merupakan kekuatan pasar yang berpengaruh terhadap harga saham. Apabila terdapat kecenderungan kenaikan permintaan saham suatu perusahaan, maka akan meningkatkan harga saham perusahaan tersebut demikian pula sebaliknya jika terjadi penurunan permintaan saham suatu perusahaan maka akan mengakibatkan turunnya harga saham perusahaan tersebut. Dalam hal ini permintaan akan suatu saham sangat dipengaruhi oleh informasi yang diterima pemodal. Baik itu informasi mengenai kondisi perusahaan yang merupakan cerminan dari kinerja perusahaan tersebut maupun informasi di luar perusahaan seperti kondisi ekonomi secara makro, kondisi pasar modal, kebijakan moneter, dan keadaan politik suatu negara, serta isu-isu yang berkaitan dengan keuangan perusahaan yang dapat mempengaruhi harga saham di pasar modal. Dan tidak kalah pentingnya adalah kemampuan pemodal dalam menganalisis saham berdasarkan informasi yang diperoleh guna menentukan saham-saham yang dapat memberikan keuntungan atas sejumlah modal yang diinvestasikan. 
Harga saham dapat dikatakan sebagai indikator keberhasilan perusahaan di mana kekuatan pasar bursa ditunjukkan dengan adanya transaksi jual beli saham di pasar modal. Terjadinya transaksi tersebut didasarkan pada pengamatan para pemodal terhadap prestasi perusahaan dalam meningkatkan keuntungan. Pemegang saham yang tidak puas terhadap prestasi manajemen akan menjual sahamnya dan menanamkan modalnya di perusahaan lain sehingga manajemen harus melaksanakan seluruh kegiatan operasional perusahaan secara efektif dan efisien untuk mencapai tujuan perusahaan dan mencapai prestasi yang diinginkan.

Bagi pemegang saham, faktor fundamental memberikan gambaran yang jelas dan bersifat analisis terhadap prestasi manajemen perusahaan dalam mengelola perusahaan yang menjadi tanggung jawabnya. Peningkatan harga saham suatu perusahaan akan menggambarkan bahwa nilai perusahaan semakin meningkat, baik ditinjau dari sudut internal perusahaan maupun pihak-pihak di luar perusahaan. Bagi manajemen perusahaan, peningkatan harga saham dapat dicapai apabila manajemen dapat menggunakan modal yang dimiliki secara efektif dan efisien. Hasil usaha yang optimal akan dapat dicapai dengan menggunakan keseluruhan modal perusahaan yang diinvestasikan dalam aktiva untuk menghasilkan keuntungan. (Kurniawan \& Indriantoro, 2000) menyebutkan bahwa adanya kandungan informasi ditunjukkan dengan perubahan harga saham sebagai bukti respon pasar.

\section{Hasil Uji Hipotesis Kedua}

Terbukti bahwa faktor rasio likuiditas, rasio leverage, rasio aktivitas, rasio profitabilitas dan rasio saham secara simultan atau bersama-sama signifikan mempengaruhi harga saham, hal ini ditunjukkan dengan Fstatistic sebesar 37.82951 dan nilai signifikansi sebesar $0,000<\alpha=0,05$.

Hasil penelitian ini mendukung penelitian (Setyaningsih, 1996) bahwa aspek-aspek yang mencerminkan kinerja keuangan perusahaan secara bersama-sama memberikan pengaruh terhadap tingkat hasil saham dan mendukung penelitian (Khajar, 2010). Temuan lainnya adalah rasio profitabilitas yang merupakan rasio kemampuan perusahaan dalam menghasilkan laba.

Teori analis fundamental dalam penilaian saham menyatakan bahwa tingkat keuntungan perusahaan akan mempengaruhi harga saham, semakin tinggi tingkat keuntungan, semakin tinggi harga saham (Husnan, 1998), kemudian (Jones, 1996) menyatakan terdapat hubungan yang sangat dekat antara keuntungan dan harga saham, dan (Akhigbe \& Madura, 1996) menyatakan terdapat hubungan antara kinerja perusahaan dengan kesejahteraan para pemegang saham. Kinerja perusahaan diukur dengan menggunakan rasio-rasio keuangan, dimana input pengukuran berasal dari laporan keuangan, dan tingkat keuntungan (profitabilitas) dapat mempengaruhi harga saham, sedangkan profitabilitas dideteksi melalui rasio keuangan Gross profit margin, Operating income ratio, Net profit margin (sales margin), Earning power of total investment (Rate of $R O A)$, Rate of return for the owners (ROE) oleh karena itu hipotesis penelitian ini memprediksi rasio keuangan bersama-sama secara signifikan berpengaruh positif terhadap harga saham dan ekspektasi return saham pada perusahaan BUMN yang listing di Bursa Efek Indonesia. Fakta empiris dari hasil penelitian menemukan bahwa secara bersama-sama terjadi pengaruh yang signifikan antara rasio likuiditas, rasio leverage, rasio aktivitas, rasio profitabilitas dan rasio saham yang terdiri dari Current ratio, Cash ratio, Quick (acid test), Total debt to equity ratio, Total debt to total capital assets, Long term debt to equity ratio, Tangible assets debt coverage, Total assets turnover, Receivables turnover, Average collection periode, Inventory turnover, Average day's inventory, Working capital turnover, Gross profit margin, Operating income ratio, Net profit margin (sales margin), Earning power of total investment (Rate of ROA), Rate of return for the owners, Price earning ratio, Dividen yield. Book value per share, dan Price to book value share) terhadap harga saham pada perusahaan BUMN yang listing di Bursa Efek Indonesia. Temuan ini mengindikasikan bahwa apabila kinerja perusahaan meningkat, maka harga saham dan ekspektasi return saham juga meningkat.

Analisis parsial menunjukkan tidak seluruh rasio keuangan memiliki pengaruh yang signifikan terhadap harga saham dan ekspektasi return saham pada perusahaan BUMN yang listing di Bursa Efek Indonesia. Hasil penelitian tersebut mendukung teori analis fundamental bahwa keuntungan/laba (rasio profitabilitas) yang dideteksi dari rasio keuangan berpengaruh terhadap harga saham dan ekspektasi return saham. Hasil penelitian ini mendukung hasil penelitian dari (Setyaningsih, 1996; Wijaya, 2013). Sedangkan analisis temuan empiris ini menolak teori analis fundamental bahwa tidak semua rasio keuangan mempunyai pengaruh positif dan signifikan terhadap harga saham. 
Faktor fundamental merupakan faktor yang memberikan informasi, tentang kinerja perusahaan dan faktor lain yang mempengaruhi. Faktor ini meliputi kemampuan manajemen dalam mengelola kegiatan operasional perusahaan untuk menghasilkan keuntungan, prospek perusahaan di masa datang, perkembangan teknologi yang digunakan dalam operasional perusahaan, hak-hak pemodal atas dana yang diinvestasikan dalam perusahaan, kemampuan perusahaan memenuhi kewajiban finansialnya terhadap pihak luar dan manfaat terhadap perekonomian nasional serta kebijaksanaan pemerintah.

\section{Hasil Uji Hipotesis Ketiga}

Tidak terbukti bahwa faktor rasio likuiditas, rasio leverage, rasio aktivitas, rasio profitabilitas dan rasio saham secara parsial signifikan mempengaruhi ekspektasi return saham. Sedangkan disisi lain terbukti bahwa faktor rasio likuiditas dan rasio aktivitas secara parsial signifikan mempengaruhi ekspektasi return saham.

Hasil penelitian ini mendukung penelitian (Suhadak, 2003), bahwa faktor fundamental berpengaruh positif terhadap keuntungan yang diharapkan (Expected return saham). Perencanaan investasi yang efektif harus dimiliki oleh seorang investor yang ingin memperoleh keuntungan di pasar modal. Bagi seorang investor keputusan investasi merupakan keputusan yang diambil untuk mengalokasikan dana yang dimiliki dalam bentuk aktiva tertentu dengan harapan mendapat keuntungan ekonomis di masa mendatang. Salah satu bentuk investasi yang dilakukan oleh para pemodal adalah dengan membeli saham, dengan harapan akan memperoleh return baik berupa dividen atau capital gain.

\section{Hasil Uji Hipotesis Keempat}

Terbukti bahwa faktor rasio likuiditas, rasio leverage, rasio aktivitas, rasio profitabilitas dan rasio saham secara simultan atau bersama-sama signifikan mempengaruhi ekspekrasi return saham, hal ini ditunjukkan dengan nilai $F$ sebesar 7.119952 dan nilai signifikansi sebesar $0,000<\alpha=0,05$. Hasil penelitian ini mendukung penelitian (Khajar, 2010).

Para investor tertarik untuk menanamkan modalnya dalam suatu perusahaan tidak hanya didasarkan pada keinginan untuk mendapatkan keuntungan jangka pendek, tetapi yang lebih penting lagi adalah prospek perusahaan dimasa depan. Prospek tersebut tidak hanya pada stabilitas dan kontinuitas perusahaan dalam pembayaran devidennya serta adanya harapan atas kenaikan harga yang diharapkan, tetapi juga mengenai prospek pertumbuhan perusahaan baik pertumbuhan pendapatan, aktiva, likuiditas, serta investasi maupun ekspansi yang dilakukan perusahaan.

Oleh karena itu bagi para investor yang bermaksud untuk terjun dalam investor di pasar modal khususnya saham di samping keuntungan yang diharapkan tentunya juga mempertimbangkan risiko apa saja yang akan timbul bila investasi ini dilakukan. Jika salah dalam memilih saham, maka akibatnya akan fatal. Investor akan menderita kerugian yang tidak terduga, investor di pasar modal memang menjanjikan keuntungan yang besar tetapi juga mengandung risiko yang besar pula. Dalam melakukan penilaian secara fundamental akan menghasilkan nilai yang mencerminkan keadaan saham yang dihubungkan dengan perusahaan yang mengeluarkan saham tersebut atau dengan emitennya. Ide dasar dari pendekatan fundamental adalah bahwa harga sekuritas akan dipengaruhi oleh kinerja perusahaan. Kinerja perusahaan itu sendiri merupakan kondisi industri.

Tujuan investor atau calon investor menginvestasikan dananya pada sekuritas adalah untuk memperoleh tingkat pengembalian (return) yang tinggi pada risiko yang tertentu, baik return jangka pendek (gain) maupun return jangka panjang (dividend). Untuk itu informasi laporan keuangan sebagai analisis fundamental dalam pengambilan keputusan seseorang untuk menginvestasikan dananya mutlak diperlukan. Investor dan calon investor sangat memerlukan pemahaman akan nilai perusahaan. Biasanya investor maupun calon investor lebih tertarik untuk melihat nilai perusahaan tersebut melalui tinggi rendahnya harga saham, profit yang dihasilkan perusahaan dan besarnya dividend yang dibagikan oleh perusahaan pada pemegang saham.

Investor harus benar-benar menyadari bahwa di samping akan memperoleh keuntungan, tidak menutup kemungkinan akan mengalami kerugian. Keuntungan dan kerugian tersebut sangat dipengaruhi oleh kemampuan investor menganalisis keadaan harga saham dan kemungkinan turun naiknya harga saham tersebut. Tinggi rendahnya harga saham merupakan penilaian sesaat yang dipengaruhi oleh banyak faktor 
termasuk diantaranya kondisi (performance) dari perusahaan, kendala-kendala eksternal, kekuatan penawaran dan permintaan saham di pasar serta kemampuan investor dalam investasi saham.

Sumber informasi yang paling umum dipergunakan oleh investor adalah laporan keuangan yang dipublikasikan. Informasi akuntansi yang terdapat dalam laporan keuangan sangat umum digunakan untuk memberikan pengungkapan mengenai kemampuan suatu perusahaan dalam mencapai tujuannya. Selain itu analisis laporan keuangan dapat mengidentifikasikan aspek-aspek laporan keuangan yang relevan untuk pembuatan keputusan investasi, sehingga dengan demikian menyajikan dasar untuk meramalkan atau memperkirakan harga saham. Profit seringkali digunakan oleh perusahaan sebagai pengukur efisiensi dan alat ramal bagi investor maupun kreditur serta pihak lain yang berkepentingan dengan perusahaan.

\section{Hasil Uji Hipotesis Kelima}

Tidak terbukti bahwa harga saham secara signifikan mempengaruhi ekspektasi return saham, dengan nilai t sebesar $-0,521$ dan signifikasi $(p=0,604)>\alpha=0,05$.

Keberadaan pasar modal dalam perekonomian suatu negara sangat penting dan komponen yang amat mendasar nilainya dalam sistem ekonomi, selain itu pasar modal juga mempunyai fungsi sarana alokasi dana yang produktif, untuk memindahkan dana dari pemberi pinjaman ke pemimjam. Dalam kaitannya dengan penanaman modal pada financial assets keputusan investasi bagi seorang investor menyangkut masa akan datang yang mengandung ketidakpastian, yang berarti mengandung unsur risiko bagi investor, maka sebagai investor yang rasional sebelum mengambil keputusan harus mempertimbangkan 2 (dua) hal yaitu pendapatan yang diharapkan (Expected Return) dan Risiko (Risk).

Investasi pada saham dikenal dengan karakteristik High Risk-High Return, artinya dinilai memberikan peluang keuntungan tinggi namun juga berpotensi risiko tinggi, dibandingkan dangan alternatif investasi yang lain seperti obligasi, deposito dan tabungan. Hal ini disebabkan oleh pendapatan saham terdiri dari deviden yang ditentukan oleh kemampuan perusahaan dalam menghasilkan laba selain itu pendapatan saham juga diperoleh dari capital gain (selisih antara harga jual dengan harga beli saham) yang ditentukan oleh fluktuasi harga saham. Seorang investor dalam melakukan investasi di pasar modal, disamping menanamkan modal juga diperlukan pengetahuan yang cukup, pengalaman, serta naluri bisnis untuk menganalisa efek atau surat berharga yang mana yang akan dibeli dan efek mana yang sudah waktunya dijual kembali.

Tujuan investor dalam berinvestasi adalah memaksimalkan return (pendapatan), tanpa melupakan faktor risiko investasi yang harus dihadapinya. Investor yang membeli saham biasa belum tentu akan mendapatkan pendapatan secara tetap dari perusahaan, karena saham biasa tidak mewajibkan perusahaan untuk membayar sejumlah kas terhadap pemegang saham. Hal ini sangat berbeda dengan obligasi yang memberikan pendapatan tetap dan waktu jatuh tempo yang sudah ditentukan, sehingga saham mempunyai risiko yang relatif lebih besar dibandingkan obligasi. Menurut (Tandelilin, 2001) risiko investasi saham bisa diartikan kemungkinan terjadinya perbedaan antara return aktual yang diterima dengan return yang diharapkan.

Kemampuan perusahaan menghasilkan laba dipengaruhi oleh faktor yang bersifat makro dan mikro, sedangkan fluktuasi harga saham dalam batas-batas tertentu juga dipengaruhi oleh faktor-faktor tersebut. Faktor-faktor yang bersifat makro merupakan faktor-faktor yang mempengaruhi kinerja semua perusahaan atau industri, misalnya seperti perubahan defisit anggaran, perubahan tingkat suku bunga, nilai kurs mata uang atau nilai tukar moneter, laju pertumbuhan inflasi dan tingkat pertumbuhan domestik bruto. Sedangkan Faktor mikro adalah spesifik dan hanya mempengaruhi perusahaan atau industri tertentu saja seperti pertunbuhan aktiva, leverage, likuiditas dan sebagainya. Kedua jenis faktor tersebut yaitu faktor makro dan mikro akan menpengaruhi tingkat risiko yang harus ditanggung investor, karena adanya perubahan faktor-faktor tersebut harga saham mengalami fluktuasi. Harga saham mencerminkan nilai perusahaan di mata masyarakat, apabila harga saham suatu perusahaan tinggi maka nilai perusahaan di mata masyarakat juga baik dan sebaliknya jika harga saham perusahaan rendah, nilai perusahaan di mata masyarakat menjadi kurang baik.

\section{Hasil Uji Hipotesis Keenam}

Terbukti bahwa faktor rasio likuiditas, rasio leverage, rasio aktivitas, rasio profitabilitas, rasio saham, dan ekspektasi return saham secara simultan atau bersama-sama signifikan menjadi bahan pertimbangan bagi 
investor dalam pengambilan keputusan berinvestasi pada perusahaan BUMN yang listing di Bursa efek Indonesia, hal ini ditunjukkan pada tabel 4.53 yang menjelaskan nilai koefisien variabel dengan nilai $\mathrm{F}$ sebesar 14,677 dan signifikasi $(\mathrm{p}=0.000)<\alpha=0,05$. Hasil penelitian ini mendukung penelitian (Kothari et al., 1995; Moses, 1999; Suhadak, 2003).

Faktor rasio likuiditas, rasio leverage, rasio aktivitas, rasio profitabilitas, rasio saham, dan ekspektasi return saham berperan dalam pengambilan keputusan seseorang mengenai investasi. Pengambilan keputusan, akan sangat dipengaruhi oleh perilaku emosi atau pengetahuan investor berkenaan dengan investasi. Masyarakat Indonesia seringkali mudah terbuai dengan berbagai janji tingkat pengembalian yang tinggi tanpa mempelajari bagaimana perusahaan atau investasi tersebut beroperasi. Satu hal yang juga dilupakan oleh para investor adalah sisi mata uang lainnya dalam berinvestasi, yaitu resiko. Karena hampir dipastikan bahwa tidak ada investasi yang memberikan keuntungan sangat fantastis tapi tidak memiliki resiko sama sekali. Oleh karenanya, perilaku keuangan individu dalam berinvestasi sangatlah penting.

\section{Temuan Penelitian}

Temuan dari analisis hasil penelitian analisis rasio keuangan pengukur kinerja perusahaan dan pengaruhnya terhadap harga saham dan ekspektasi return saham sebagai bahan pengambilan keputusan bagi investor diuraikan sebagai berikut:

Hasil penelitian menunjukkan bahwa faktor kinerja perusahaan yang diukur dari rasio likuiditas, rasio leverage, rasio aktivitas, rasio profitabilitas dan rasio saham secara parsial tidak sepenuhnya berpengaruh signifikan terhadap harga saham. Dengan demikian, hasil penelitian ini menolak hipotesis pertama $\left(\mathrm{H}_{1}\right)$. Fakta empiris menunjukkan, bahwa peningkatan indikator-indikator faktor kinerja perusahaam (rasio likuiditas, rasio leverage, rasio aktivitas, rasio profitabilitas dan rasio saham) tidak meningkatkan secara langsung terhadap harga saham. Berdasarkan temuan penelitian ini dapat disimpulkan, bahwa bukti data empiris tidak sesuai dengan teori yang menyatakan: Semakin baik indikator kinerja keuangan perusahaan, maka semakin tinggi harga saham.

Hasil penelitian menunjukkan bahwa faktor kinerja perusahaan yang diukur dari rasio likuiditas, rasio leverage, rasio aktivitas, rasio profitabilitas dan rasio saham secara simultan berpengaruh signifikan terhadap harga saham. Dengan demikian, hasil penelitian ini menerima hipotesis kedua $\left(\mathrm{H}_{2}\right)$. Fakta empiris menjelaskan, bahwa faktor kinerja perusahaan (rasio likuiditas, rasio leverage, rasio aktivitas, rasio profitabilitas dan rasio saham) berpengaruh signifikan terhadap harga saham. Hasil ini memberikan keputusan, bahwa dari koefisien yang diperoleh telah menunjukkan adanya pengaruh yang signifikan. Dengan demikian, hipotesis penelitian yang menyatakan, bahwa faktor kinerja perusahaan secara simultan berpengaruh signifikan terhadap harga saham dapat diterima.

Hasil penelitian menunjukkan bahwa faktor kinerja perusahaan yang diukur dari rasio likuiditas, rasio leverage, rasio aktivitas, rasio profitabilitas dan rasio saham secara parsial tidak sepenuhnya berpengaruh signifikan terhadap ekspektasi return saham. Dengan demikian, hasil penelitian ini menolak hipotesis ketiga $\left(\mathrm{H}_{3}\right)$. Fakta empiris menunjukkan bahwa peningkatan indikator-indikator faktor kinerja perusahaan tidak langsung meningkatkan indikator ekspektasi return saham. Berdasarkan temuan penelitian ini dapat disimpulkan, bahwa bukti empiris tidak sesuai dengan teori yang menyatakan semakin baik indikator kinerja keuangnan perusahaan, maka semakin tinggi tingkat keuntungan yang diharapkan (expected return) oleh investor. Hasil ini memberikan keputusan bahwa dari koefisien variabel yang diperoleh telah menunjukkan tidak adanya pengaruh yang signifikan. Dengan demikian, hipotesis penelitian tidak dapat diterima atau tertolak secara statistik.

Hasil penelitian menunjukkan bahwa faktor kinerja perusahaan yang diukur dari rasio likuiditas, rasio leverage, rasio aktivitas, rasio profitabilitas dan rasio saham secara simultan berpengaruh signifikan terhadap ekspektasi return saham. Dengan demikian, hasil penelitian ini menerima hipotesis keempat $\left(\mathrm{H}_{4}\right)$. Fakta empiris menjelaskan, bahwa faktor kinerja perusahaan (rasio likuiditas, rasio leverage, rasio aktivitas, rasio profitabilitas dan rasio saham) berpengaruh signifikan terhadap ekspektasi return saham. Hasil ini memberikan keputusan, bahwa dari koefisien yang diperoleh telah menunjukkan adanya pengaruh yang signifikan. Dengan demikian, hipotesis penelitian yang menyatakan, bahwa faktor kinerja perusahaan secara simultan berpengaruh signifikan terhadap ekspektasi return saham dapat diterima.

Hasil penelitian menunjukkan bahwa harga saham tidak berpengaruh signifikan terhadap ekspektasi return saham. Dengan demikian, hasil penelitian ini menolak hipotesis kelima $\left(\mathrm{H}_{5}\right)$. Fakta empiris 
menyatakan, bahwa peningkatakan harga saham tidak akan meningkatkan tingkat keuntungan yang diharapkan (expected return) oleh investor. Berdasarkan temuan penelitian ini dapat disimpulkan, bahwa bukti empiris tidak sesuai dengan teori yang menyatakan: Semakin tinggi harga saham, maka akan semakin meningkatkan tingkat keuntungan yang diharapkan (expected return) oleh investor. Hasil ini memberikan keputusan, bahwa dari koefisien variabel yang diperoleh telah menunjukkan tidak adanya pengaruh yang signifikan. Dengan demikian, hipotesis penelitian yang menyatakan, bahwa harga saham berpengaruh signifikan terhadap ekspektasi return saham tidak dapat diterima atau tertolak secara statistik.

Hasil penelitian menunjukkan bahwa kinerja perusahaan, harga saham dan ekspektasi return saham menjadi bahan pertimbangan bagi investor dalam pengambilan keputusan untuk berinvestasi pada perusahaan BUMN yang listing di Bursa Efek Indonesia. Fakta empiris menyatakan, bahwa peningkatankan kinerja perusahaan, harga saham dan ekspektasi return saham akan meningkatkan pengambilan keputusan yang diambil oleh investor. Berdasarkan temuan penelitian ini dapat disimpulkan, bahwa bukti empiris sesuai dengan teori yang menyatakan: Semakin tinggi kinerja perusahaan, harga saham dan ekspektasi return saham, maka akan semakin meningkatkan tingkat pengambilan keputusan yang diambil oleh investor. Hasil ini memberikan keputusan, bahwa dari deskripsi hasil data lapangan variabel yang diperoleh telah menunjukkan bahwa kinerja perusahaan, harga saham dan ekspektasi return saham dijadikan bahan pertimbangan dalam pengambilan keputusan bagi investor dalam berinvestasi di pasar modal. Hal ini didukung dari jawaban responden yang menyatakan sering (58,7\%) mempertimbangkan faktor rasio likuiditas, rasio leverage, faktor aktivitas, rasio profitabilitas, dan rasio saham pengukur kinerja perusahaan dijadikan sebagai bahan pertimbangan dalam pengambilan keputusan membeli saham perusahaan BUMN yang listing di Bursa Efek Indonesia.

\section{Pembahasan}

\section{M odel yang D irekomendasikan}

Berdasarkan temuan empirik melalui metode kuantitatif maka model yang direkomendasikan seperti terlihat pada gambar 2 berikut ini:

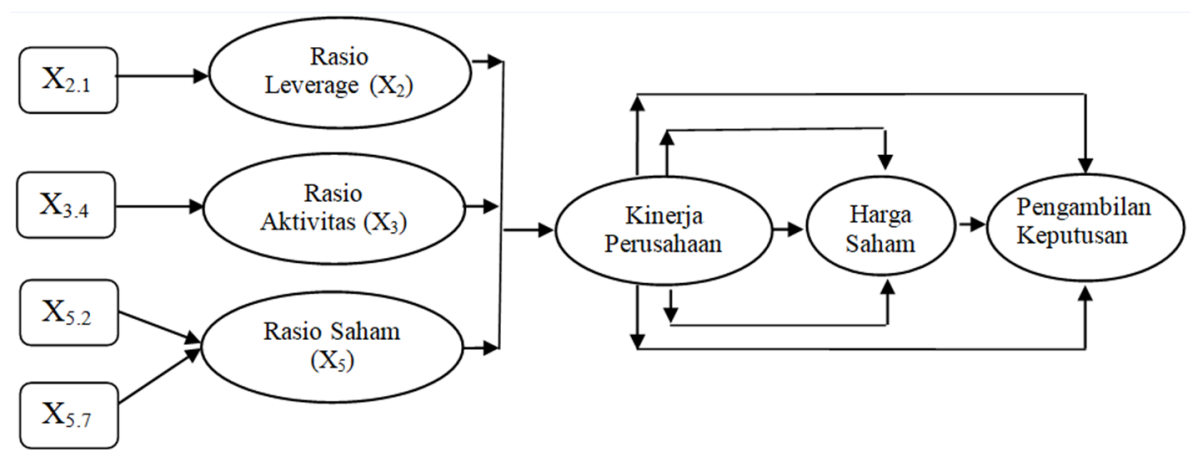

Gambar 2 : Model yang Direkomendasikan

Keterangan: $\mathrm{X}_{2.1}=$ Total debt to equity ratio

$\mathrm{X}_{3.4}=$ Working capital turnover

$\mathrm{X}_{5.2}=$ Earnig per share (EPS)

$\mathrm{X}_{5.7}=$ Price to book value share

Implikasi atas model gambar $2 \mathrm{ini}$, bahwa rasio leverage yang terdiri dari: Total debt to equity ratio, rasio aktivitas yang terdiri dari Working capital turnover dan rasio saham yang terdiri dari Earnig per share (EPS) dan Price to book value share dapat mengukur kinerja perusahaan. Kinerja perusahaan yang diukur dari rasio-rasio keuangan tersebut secara parsial berpengaruh signifikan terhadap harga saham, dan secara simultan kinerja perusahaan yang diukur dari rasio-rasio keuangan berpengaruh signifikan terhadap harga 
saham. Harga saham dari deskripsi data lapangan menjadi bahan pertimbangan bagi investor dalam pengambilan keputusan berinvestasi di pasar modal.

Dari temuan empiris menunjukkan bahwa kinerja perusahaan mempengaruhi harga saham dan harga saham menjadi bahan pertimbangan dalam pengambilan keputusan bagi investor dalam berinvestasi di pasar modal maka, pihak manajemen perusahaan perlu memperhatikan dan meningkatkan kinerja perusahaan yang dipimpinnya, karena investor mempertimbangkan kinerja perusahaan dalam pengambilan keputusan untuk berinvestasi. Berdasarkan temuan empirik melalui metode kuantitatif dimana faktor harga saham tidak berpengaruh terhadap ekspektasi return saham, maka model yang direkomendasikan seperti terlihat pada Gbr 3.

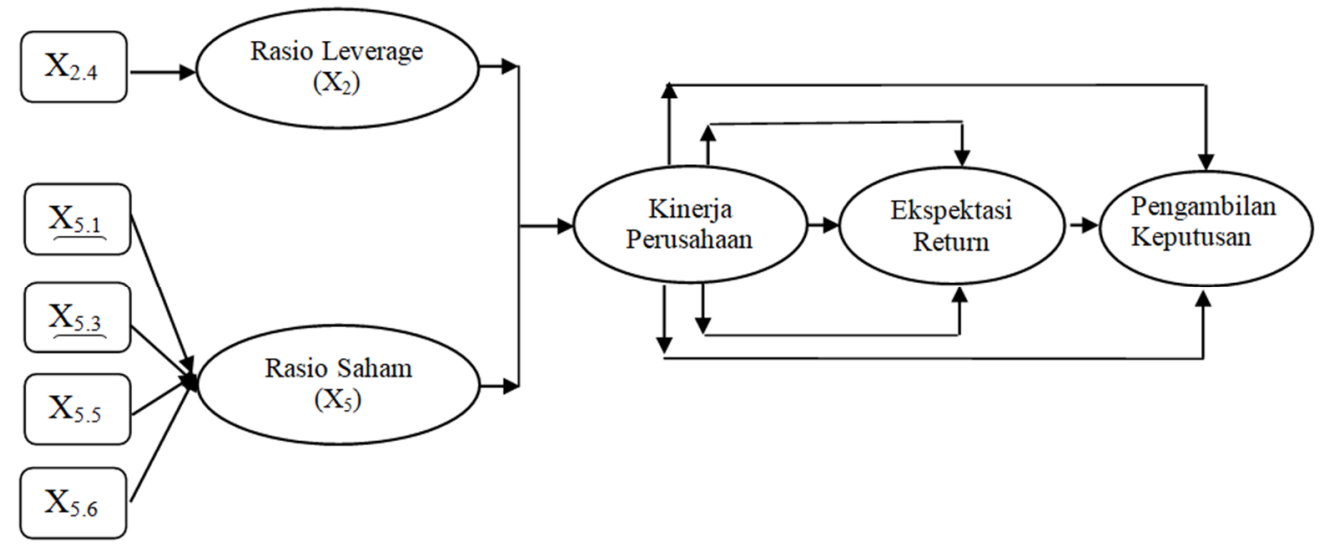

Gambar 3. Model yang Direkomendasikan

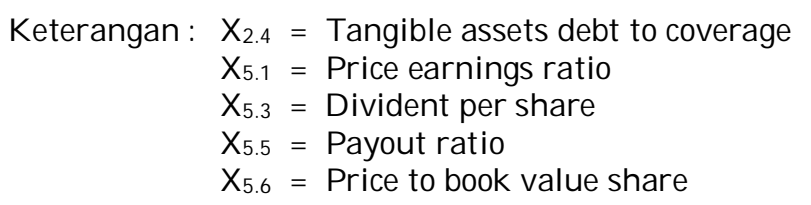

Implikasi atas model gambar $3 \mathrm{ini}$, bahwa rasio leverage yang terdiri dari Tangible assets debt to coverage dan rasio saham yang terdiri dari Price earnings ratio, Divident per share, Payout ratio dan Price to book value share dapat mengukur kinerja perusahaan. Kinerja perusahaan yang diukur dari rasio-rasio keuangan teresbut secara parsial berpengaruh signifikan terhadap ekspektasi return saham, dan secara simultan kinerja perusahaan yang diukur dari rasio-rasio keuangan berpengaruh signifikan terhadap ekspektasi return saham. Harga saham tidak berpengaruh signifikan terhadap ekspektasi return saham. Kinerja perusahaan, dan ekspektasi return saham dari deskripsi data lapangan menjadi bahan pertimbangan bagi investor dalam pengambilan keputusan berinvestasi di pasar modal.

Dari temuan empiris menunjukkan bahwa kinerja perusahaan mempengaruhi ekspektasi return saham, ekspektasi return saham menjadi bahan pertimbangan dalam pengambilan keputusan bagi investor dalam berinvestasi di pasar modal, maka pihak manajemen perusahaan perlu memperhatikan dan meningkatkan kinerja perusahaan yang dipimpinnya, karena investor mempertimbangkan kinerja perusahaan dalam pengambilan keputusan untuk berinvestasi.

\section{SIMPULAN DAN SARAN}

\section{Simpulan}

Rasio leverage yang terdiri dari Total debt to equity ratio dan Tangible assets debt coverage, dan rasio saham yang terdiri dari Dividen yield dan Price to book value share secara parsial berpengaruh signifikan terhadap harga saham perusahaan BUMN yang listing di Bursa Efek Indonesia. Rasio likuiditas, rasio leverage, rasio aktivitas, rasio profitabilitas dan rasio saham secara simultan berpengaruh signifikan 
terhadap harga saham perusahaan BUMN yang listing di Bursa Efek Indonesia. Rasio leverage yang terdiri tangible assets debt coverage dan rasio saham yang terdiri dari price earning ratio, dividend per share, pay out ratio dan book value per share secara parsial berpengaruh signifikan terhadap ekspektasi return saham perusahaan BUMN yang listing di Bursa Efek Indonesia.

Rasio likuiditas, rasio leverage, rasio aktivitas, rasio profitabilitas dan rasio saham secara simultan berpengaruh signifikan terhadap ekspektasi return saham perusahaan BUMN yang listing di Bursa Efek Indonesia. Faktor harga saham tidak berpengaruh signifikan terhadap ekspektasi return saham. Dimana terdapat pengaruh negatif dan tidak signifikan antara harga saham terhadap ekspektasi return saham. Rasio saham yang diukur dengan price to book value share merupakan faktor dominan yang mempengaruhi harga saham. Sedangkan rasio likuiditas yang diukur dengan quick (acid test) merupakan faktor dominan mempengaruhi ekspektasi return saham. Faktor rasio keuangan pengukur kinerja perusahaan, harga saham dan ekspektasi return saham sering menjadi bahan pertimbangan bagi investor dalam pengambilan keputusan berinvestasi pada perusahaan BUMN yang listing di Bursa efek Indonesia.

\section{Saran}

Pihak investor dan calon investor perlu meningkatkan kemampuannya melihat dan menilai rasio-rasio keuangan entitas dengan meningkatkan pengetahuan dan pendidikan mengenai ekonomi lebih khusus tentang manajemen keuangan, analisis investasi dan pasar modal, dengan demikian hasil yang diharapkan (ekspektasi return) akan mendorong investor dan calon investor untuk mengambil keputusan berinvestasi pada saham perusahaan BUMN yang listing di Bursa Efek Indonesia. Dari investasi yang dilakukan investor pihak perusahaan akan memperoleh tambahan dana untuk operasional dan mampu meningkatkan keuntungan, sehingga laba yang dibagikan (dividen) akan meningkat dan mendorong naiknya harga saham yang diperdagang di pasar modal. Disisi lain para investor akan memperoleh hasil yang diharapkan dalam bentuk dividen dan capital gain yang lebih meningkat.

Pihak manajemen lebih fokus untuk meningkat pencapaian tujuan perusahaan yaitu untuk mendapatkan keuntungan, sehingga tujuan jangka panjang investor untuk mendapatkan dividen yang dibagikan dengan nilai yang lebih besar akan mampu menciptakan daya tarik yang lebih baik bagi investor untuk berinvestasi pada saham perusahaan yang diperdagangkan di pasar modal.

Karena investor akan mempertimbangkan kinerja perusahaan, harga saham dan ekspektasi return saham serta faktor lain di luar dari variabel yang diteliti dalam pengambilan keputusan untuk berinvestasi, sebaiknya pihak manajemen perusahaan meningkatkan kinerjanya melalui peningkatan sumber daya manusianya agar mampu melakukan efisiensi dalam pengelolaan perusahaan untuk mewujudkan tujuan mendapatkan dan meningkatkan keuntungan dengan mengikutkan para pemimpin (staf dan karyawan) perusahaan yang lainnya dalam pendidikan pada jabatan (in-service education) dan pelatihan ke lembagalembaga pendidikan terkait. Sehingga pengetahuan dapat meningkatkan kinerja manajemen yang berdampak pada peningkatan terhadap faktor kinerja perusahaan.

Untuk meningkatkan peluang dari potensi yang dimiliki masyarakat dalam berinvestasi cukup besar, terutama pada pasar modal. Lembaga pendidikan punya andil besar untuk mengembangkan kemampuan dan pengetahuan masyarakat berinvestasi pada pasar modal sebagai upaya pemberdayaan sumber dana dalam negeri dan meningkatkan partisipasi masyarakat dalam pembangunan ekonomi negara dan bangsa serta pemerataan kepemilikan perusahaan dan pemerataan pendapatan bagi masyarakat. Untuk itu sebaiknya di sekolah-sekolah menengah tingkat atas dan atau di perguruan tinggi diberikan materi ekonomi yang diperluas dengan keuangan, investasi dan pasar modal, sehingga masyarakat akan memahami tentang arti pentingnya investasi dan peran investor dalam pembangunan suatu Negara, yaitu dapat menciptakan peluang/kesempatan kerja, mengurangi tingkat pengangguran, meningkatkan laju pertumbuhan ekonomi dan lain sebagainya.

\section{DAFTAR PUSTAKA}

Akhigbe, A., \& Madura, J. (1996). Dividend policy and corporate performance. Journal of Business Finance \& Accounting, 23(9-10), 1267-1287.

Harianto, F., \& Sudomo, S. (1998). Perangkat dan teknik analisis Investasi di pasar Modal Indonesia. BEJ, Jakarta.

Harijono, I. (2006). Analisis Pengaruh Beberapa Variabel Fundamental dan Teknikal terhadap Perubahan Harga Saham (Studi Kasus Perusahaan Farmasi yang Go Publik Di Bursa Efek Jakarta). Jurnal Akademika, 3(1). 
Husnan, S. (1998). Dasar-dasar Teori Portofolio dan Analisis Sekuritas. Edisi Kedua. Yogyakarta: UPP-AMP YKPN. Scott, William R. 2003. Financial Accounting Theory. Third Edition. University.

Jones, C. P. (1996, March 19). Apparatus and method for generating product coupons in response to televised offers. Google Patents.

Khajar, I. (2010). Pengaruh Right Issue Terhadap Kinerja Keuangan Perusahaan. Jurnal Dinamika Manajemen, 1(1).

Kothari, S. P., Shanken, J., \& Sloan, R. G. (1995). Another look at the cross-section of expected stock returns. The Journal of Finance, 50(1), 185-224.

Kurniawan, H., \& Indriantoro, N. (2000). Analisis Hubungan Antara Arus Kas dari Aktivitas Operasi dan Data Akrual Dengan Return Saham: Studi Empiris pada Bursa Efek Jakarta. Jurnal Bisnis Dan Akuntansi, 2(3), $207-224$.

Moses, J. (1999). Equilibrium in a Capital Asset Pricing Market. Econometrica, 34, 78-83.

Rachbini, D. J. (1992). Peranan Ekonomi Negara (Tinjauan Teoritis dan Praktis) lihat dalam: Peran BUMN Dalam Ekonomi Kapitalis. Prisma Majalah Pemikiran Sosial Ekonomi, (2).

Setyaningsih, S. (1996). Analisis Perbedaan Kinerja Keuangan Pemsahaan Sebelum dan Sesudah Go-Publik serta Pengaruhnya terhadap Tingkat hasil Saham di Pasar modal Indonesia, Thailand dan Jepang. Universitas Airlangga.

Suhadak, S. (2003). Pengaruh Faktor Fundamental terhadap Keuntungan yang Diharapkan Melalui Risiko Pasar di Bursa Efek Jakarta Indonesia. Universitas Airlangga.

Supriyono, R. A. (1999). Manajemen Biaya Suatu Reformasi Pengelolaan Bisnis. Yogyakarta: BPFE.

Tandelilin, E. (2001). Analisis investasi dan manajemen portofolio. Yogyakarta: Bpfe.

Wijaya, A. P. (2013). Analisis Rasio Keuangan dalam Merencanakan Pertumbuhan Laba: Perspektif Teori Signal. Kajian Ilmiah Mahasiswa Manajemen, 2(2).

Yuwono, S., Sukarno, E., \& Ichsan, M. (2002). Petunjuk Praktis Penyusunan Balanced Scorecard: Menuju Organisasi yang Berfokus pada Strategi. Penerbit PT Gramedia Pustaka Utama, Jakarta.

Zuhroh, S. (2004). Pengaruh Faktor Fundamental Perusahaan terhadap Harga Saham. Pasca Publikasi Laporan Keuangan pada Kelompok Industri Farmasi dan Minuman di BEJ. Universitas Airlangga. 